In conclusion, therefore, in dealing with the conversion of plants and animals into human food it is not with their comparative merits that we have to deal but with their complementary merits. An agricultural system devoid of livestock is not an efficient method of using our land nor is a system based in its entirety on livestock production.

\title{
REFERENCES
}

Andross, M. (1946). Proc. Nutr. Soc. 4, 155.

Block, R. J. \& Bolling, D. (1945). The Amino Acid Composition of Proteins and Foods, 1st ed. Springfield, Illinois: Chas. C. Thomas.

Booth, R. G., Carter, R. H., Jones, C. R. \& Moran, T. (1946). In The Nation's Food, p. 162. [A. L. Bacharach and T. Rendle, editors.] London: Society of Chemical Industry.

Bricker, M., Mitcheil, H. H. \& Kinsman, G. M. (1945). F. Nutrit. 30, 269.

Chick, H. \& Slack, E. B. (1945). Biochem. F. 39, xxii.

Halnan, E. T. (1944). Proc. Nutr. Soc. 1, 32.

Hrdlicka, A. (1936). Proc. Amer. Phil. Soc. 76, 847.

Kon, S. K. (1946a). In The Nation's Food, p. 318. [A. L. Bacharach and T. Rendle, editors.] London: Society of Chemical Industry.

Kon, S. K. (1946b). In The Nation's Food, p. 14. [A. L. Bacharach and T. Rendle, editors.] London: Society of Chemical Industry.

Lampitt, L. H. \& Goldenberg, N. (1946). In The Nation's Food, p. 58. [A. L. Bacharach and T. Rendle, editors.] London: Society of Chemical Industry.

Leitch, I. (1944). Proc. Nutr. Soc. 1, 60.

Leitch, I. \& Godden, W. (194I). Tech. Commun. Bur. Animal Nutrit. no. 14.

Lockwood, J. F. (1945). Provender Milling, and ed. Liverpool: Northern Publishing Co. Ltd.

McCance, R. A. \& Widdowson, E. M. (1946). Spec. Rep. Ser. med. Res. Coun., Lond., and ed., no. 235.

Macy, I. G. (1943). See Block, R. J., Yale F. Biol. Med. 15, 723.

Mitchell, H. H. (1924). Physiol. Rev. 4, 424.

National Research Council (1943). Repr. nat. Res. Coun., Wash., no. 115.

Orr, J. (1944). Proc. Nutr. Soc. 1, 43.

Pyke, M. (1946). In The Nation's Food, p. 108. [A. L. Bacharach and T. Rendle, editors.] London: Society of Chemical Industry.

Rose, W. C. (1949). Fed. Proc. 8, 546.

Watson, J. A. S. \& More, J. A. (1942). Agriculture, the Science and Practice of British Farming, 6th ed. Edinburgh: Oliver and Boyd.

Wood, T. B. \& Newman, L. F. (1928). Beef Praduction in Great Britain. Liverpool: Silcock and Sons Ltd.

\section{Economic and Statistical Aspects of Vegetable and Animal Foods}

\section{By D. A. BOYD, Rothamsted Experimental Station, Harpenden, Herts.}

In deciding what balance of vegetable and animal foods shall be available to the population of this country the relative nutritional and gastronomical values of the foods have to be weighed very carefully against what is economically practical. Though we know that it is possible to live and work on a diet containing only a very small contribution of animal protein and fats, most of us would probably work better and live more happily on a more mixed diet containing a larger amount of animal foods. The balance between the two types of food is largely determined by three factors: the acreage of land available for agriculture, the size of the agricultural labour force, and the extent to which we can rely on imported food. In this paper, I shall first indicate the relation of these economic factors to the physiological aspects of vegetable and animal foods, and then give some indication of how far home agriculture can be expected to make a greater contribution to our food requirements. 


\section{Physiological efficiency}

Since to a considerable extent animals eat foods that could be utilized for human consumption or use land that could be cropped with cereals or potatoes, a measure of the efficiency of conversion of feeding-stuffs to human foods by animals is essential. There has been in the past some disagreement on the most appropriate measure to use; it will be as well therefore to consider first what is the best measure of efficiency and how it should be obtained. The yield of protein expressed as a percentage of the amount of protein fed has been widely used as an index of physiological efficiency; but this would only be a satisfactory measure if protein was the chief factor limiting further production. In fact, though lack of protein may be of major importance on some individual farms, particularly poultry farms, the livestock production in general is restricted not by lack of protein but by the available energy supplies. Sufficient protein for dairy cattle and other stock can be provided from home-grown foods and the ration of concentrates. The principal measures of efficiency that are of interest are therefore the ratio of proteins, fats, vitamins and other nutrients produced per unit of energy supplied in the feed. If the protein supplies of the population are critical, the first measure will be of greatest interest, but if fats are also short the ratio of the total energy produced (available to human beings) to the energy supplied may provide an adequate overall index.

In making assessments of this kind it is not sufficient to take the conventional allowances for maintenance and production for the adult animal. With the dairy cow, for example, allowance must also be made for the food required in the production and rearing of the calf up to the beginning of lactation, for maintenance during the dry period and for the food required to fatten her off when she leaves the dairy herd. On the credit side will be the milk produced in the course of, say, 5 years of productive life and the food value of the carcass. Similar calculations may be made for other types of livestock. These give the efficiencies shown in Table $\mathrm{I}$.

Table 1. Efficiency of conversion of food by farm animals

\begin{tabular}{|c|c|c|c|c|c|c|}
\hline \multirow[b]{3}{*}{ Kind of stock } & \multicolumn{5}{|c|}{$\begin{array}{l}\text { Energy produced (as percentage of } \\
\text { available energy in food) }\end{array}$} & \multirow{3}{*}{$\begin{array}{l}\text { Protein } \\
\text { produced (as } \\
\text { percentage } \\
\text { of protein } \\
\text { equivalent } \\
\text { fed) }\end{array}$} \\
\hline & \multirow[b]{2}{*}{$\underset{\text { protein* }}{\text { As }}$} & \multirow[b]{2}{*}{ As fat* } & \multirow[b]{2}{*}{$\begin{array}{l}\text { As carbo- } \\
\text { hydrate* }\end{array}$} & \multicolumn{2}{|c|}{ Total } & \\
\hline & & & & $\begin{array}{l}\text { Present } \\
\text { data* }\end{array}$ & $\begin{array}{l}\text { r917 } \\
\text { datat }\end{array}$ & \\
\hline $\begin{array}{l}\text { Dairy cows } \\
\text { Beef cattle }\end{array}$ & $\begin{array}{l}3.7 \\
1.6\end{array}$ & $\begin{array}{r}11 \cdot 1 \\
5 \cdot 2\end{array}$ & $4 \cdot 6$ & $\begin{array}{r}19.4 \\
6.8\end{array}$ & $\begin{array}{r}15.0 \\
6.7\end{array}$ & $\begin{array}{l}23 \\
10\end{array}$ \\
\hline Sheep & $1 \cdot 3$ & $7 \cdot 5$ & - & $8 \cdot 8$ & $10 \cdot 4$ & II \\
\hline Pigs & $x \cdot 8$ & $16 \cdot 7$ & - & $18 \cdot 5$ & $17 \cdot 9$ & 12 \\
\hline Fowls & $3 \cdot 0$ & $6 \cdot 7$ & - & $9 \cdot 7$ & $7 \cdot 7$ & 32 \\
\hline
\end{tabular}

Similar figures for total energy produced, prepared during the 1914-18 war (Royal Society, 1917), are also shown for comparison. 
Though there are considerable differences in efficiency between the different farm animals, Table $\mathrm{I}$ shows that, regarded merely as converters of energy, all animals are decidedly wasteful. In round figures, it takes ten units of energy (available to the livestock), to produce one unit of energy available to human beings. On the energy : energy basis dairy cattle and pigs are outstandingly more efficient than the other livestock; on the protein : energy basis dairy cows again lead, closely followed by fowls. It will be seen from the last column of the table that the chief effect of the inappropriate protein : protein ratio is to overvalue the contribution of fowls relative to other livestock.

\section{Some economic considerations}

There are important qualifications to be noted in using these purely physiological measures of efficiency. Farm animals, particularly herbivores, can utilize foods that are of no value to human beings. Beef cattle and sheep come out very low on each assessment; but to a considerable extent they are the product, as stores, of the hill and marginal land often unsuited to any other branch of farming.

Another qualification arises from the differences in yield/acre of the different crops, resulting in varying land requirements for the different forms of livestock. Estimates of yield/acre are given in Table 2. It is not entirely satisfactory to use

Table 2. Yield in cwt./acre of available energy and protein from different crops

\begin{tabular}{|c|c|c|}
\hline Crop & $\begin{array}{l}\text { Starch } \\
\text { equivalent }\end{array}$ & $\begin{array}{l}\text { Protein } \\
\text { equivalent }\end{array}$ \\
\hline $\begin{array}{c}\text { Cereals: } \\
\text { Grain } \\
\text { Straw" }\end{array}$ & $\begin{array}{r}14 \\
2\end{array}$ & $\begin{array}{l}x \cdot 7 \\
0.1\end{array}$ \\
\hline Potatoes & 28 & $1 \cdot 3$ \\
\hline Kale & 27 & $4 \cdot 2$ \\
\hline $\begin{array}{l}\text { Grass: } \\
\text { First-grade ryegrass pasture } \\
\text { Second-grade pasture } \\
\text { Poor agrostis pasture } \\
\text { Rough grazings }\end{array}$ & $\begin{array}{c}20-40 \\
13-19 \\
6-12 \\
0-5\end{array}$ & $\begin{array}{l}3 \cdot 0-4 \cdot 0 \\
1 \cdot 8-3 \cdot 0 \\
0 \cdot 6-1 \cdot 8 \\
0.0-0 \cdot 5\end{array}$ \\
\hline
\end{tabular}

- Assuming that three-quarters of the oat straw and one-quarter of the wheat and barley straw are utilized.

average values, since some parts of the country, owing to soil and climatic conditions, are more suited to one type of crop than another. The yield of grass is particularly variable, owing in part to these factors but mainly to variations in management; a series of estimated yields is shown to indicate the range. The relative yields of cereals and grass are of particular interest; they show that good grass in a suitable district can yield fully half as much again as cereals, and at the expense of less labour. Indeed it is possible by heavy nitrogen dressings for grass drying or storage to push up yields of grass very much further. Thus if grass can be made to yield twice as much as cereals the dairy cow will produce $2 \times 19.4 \%$, or nearly $40 \%$, of the energy value of a cereal crop. 
A third qualification to be noted in the data of Table $\mathrm{I}$ arises from the very different labour requirements of the different forms of livestock. Estimates of the man-hours/cwt. starch equivalent produced are shown in Table 3 .

Table 3. Labour requirements of farm animals and crops

(Man-hours/cwt. starch equivalent produced)'

$\begin{array}{lcc}\text { Animal: } & \begin{array}{c}\text { Direct } \\ \text { requirements }\end{array} & \begin{array}{c}\text { Total labour } \\ \text { requirements* }\end{array} \\ \text { Dairy cows } & 24 & 30 \\ \text { Bullocks } & 12 & 15 \\ \text { Sheep } & 10 & 12 \\ \text { Pigs } & 5 & 23 \\ \text { Fowls } & 24 & 52 \\ \text { Crop: } & & \\ \text { Wheat } & 3 & - \\ \text { Sugar beet } & 8 & - \\ \text { Potatoes } & 7 & -\end{array}$

- Including labour requirement for harvest and storage of feeding-stuffs.

$\dagger$ Assuming $12 \%$ sugar yield.

Dairy cows have twice the labour requirements of bullocks, per unit of energy produced, and rather more than twice the requirements of sheep. Pigs, which Table I shows to be relatively efficient on the energy : energy basis, absorb relatively little direct labour, but most of their food has to be harvested and stored; moreover, the foods themselves are to a considerable extent directly consumable by human beings. The hen is expensive in direct labour, and in the main requires stored foods.

The second part of the table shows that for equal amounts of available energy produced the labour requirements for growing and harvesting cereal crops are far below the labour requirements for animals; the farm labour requirements of root crops are about half the total labour requirements for bullocks and sheep.

Sufficient has been said to show the limitations to which estimates of purely physiological efficiency are subject when we are considering the supplies of vegetable and animal foods from the wider economic angle. The construction of a table similar to Table I but in terms of economic efficiency would, however, be a formidable task. Thus we would have to balance the relative values of land units given by Table 2 against the labour units of Table 3 ; to these we would have to add similar complex problems affecting, for example, rent and capital. A simpler and more direct approach is possible by considering the selling price of the different livestock products. Within the country the prices of the different crop and livestock products, although fixed by negotiations between the producers and the ministries, are likely to bear sufficient relation to actual costs of production to form a rough overall integration of the different factors already discussed. The prices paid to the farmer in relation to the energy produced ( $f$ /cwt. starch equivalent) are shown in Table 4. On the basis of farmers' prices the cost of energy produced by the dairy cow is well below that from other livestock. At the same time, now that liquid milk supplies are adequate, it would be reasonable to expect any additional supplies to be converted into cheese or butter, 
thereby substantially increasing the cost per unit energy. Fowls and beef cattle, though expensive on the energy basis, come very close to milk on cost per unit protein. No allowance has been made for wastage or distribution costs, which will affect milk and eggs more seriously than meat, or for the value of hides and other by-products which will reduce somewhat the costs for cattle, sheep and pigs.

Table 4. Cost of energy in vegetable and livestock products

(£/cwt. starch equivalent, 1949-50 prices)

\begin{tabular}{lcc} 
Animal: & $\begin{array}{c}\text { Farmers' } \\
\text { price }\end{array}$ & $\begin{array}{c}\text { Import } \\
\text { price }\end{array}$ \\
Dairy cows (milk) & $8 \cdot 8$ & - \\
Beef cattle & $12 \cdot 2$ & $6 \cdot 4$ \\
Sheep & $13 \cdot 8$ & $6 \cdot 8$ \\
Pigs & $10 \cdot 3$ & $7 \cdot 2$ \\
Fowls (eggs) & $15 \cdot 2$ & $10 \cdot 5$ \\
Crop: & & \\
Cereals & $2 \cdot 0$ & $1 \cdot 9$ \\
Potatoes & $2 \cdot 8$ & - \\
Sugar beet* & $2 \cdot 2$ & - \\
\multicolumn{2}{c}{ Assuming $12 \%$ sugar yield. }
\end{tabular}

Costs of energy from crops for human consumption are also shown in Table 4. No allowances have been made for processing of cereals and sugar beet, or for the high wastage of potatoes. In round figures, it appears that one unit of available energy from livestock is four to six times as expensive as a unit from crops.

As a matter of interest, import prices are also given in Table 4; the prices are comparable subject to the quality considerations in favour of the home product.

\section{Current agricultural production}

In the light of the foregoing discussion, it is of interest to consider briefly the amount and nature of the total food supplies of the country. In Table 5 are shown the energy

Table 5. Energy equivalents of total available food supplies of the United Kingdom, 1945*

Home-produced foods:

Vegetable: Tillage crops

Temporary and permanent grass

Rough grazing

Total

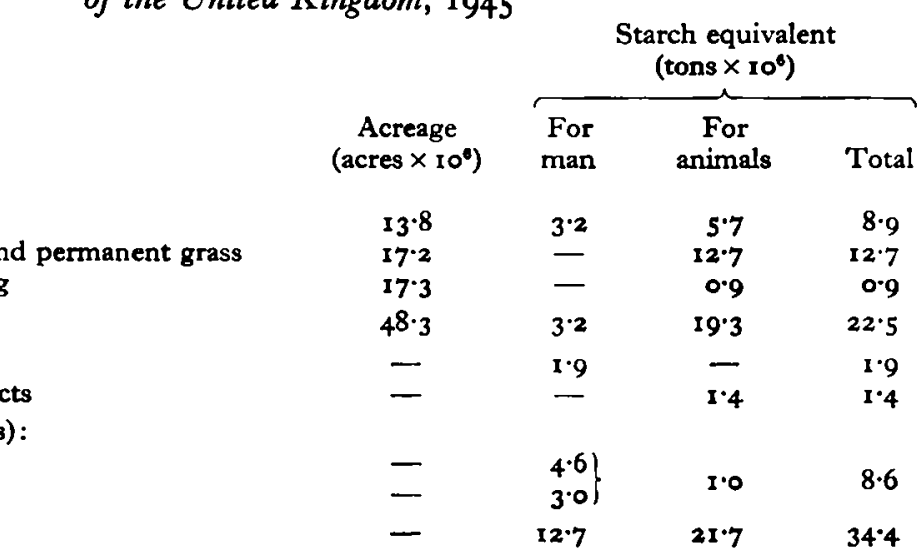

Animal

Manufacturing by-products

Imported foods (net imports):

Vegetable

Animal

Total

- Most of the estimates in the table are those given by the Central Statistical Office (1950), but some details are from unpublished data supplied by the Ministry of Agriculture. 
values of home-grown foods going directly to human beings and to livestock; the table shows how the total supplies for man are divided between home production and imports and between vegetable and animal foods.

Home produce in 1945 supplied about $40 \%$ of the total energy requirements of the population, $25 \%$ coming direct from crops and $15 \%$ through the animal. The ratio of home production to imports was much the same for vegetable and animal sources. Although the output of home-produced animal foods was barely $40 \%$ of our requirements, the animals consumed $86 \%$ of the total energy available.

The quantity of vegetable foods for human consumption in $1945^{-6}$ was almost double the prewar figure, and this level of production has been maintained in the postwar period. The output of animal products has recovered from the low figures of the war years and in 1949-50 was a little above that of 1936-8; the reduction in pigs and sheep was more than outweighed by the increase in milk. There was a considerable reduction in the importation of animal feeding-stuffs. If allowance is made for this, the net output shows an increase over prewar values of one-third by $1945^{-6}$ and of almost one-half by 1949-50.

The arable side of our farms is in the main now running at a high level of productivity, and no large increases can be expected from this source without cutting into the large acreage at present devoted to livestock. Though greater efficiency appears to have been partly responsible for the increase in dairy production, there is no doubt that further increases in efficiency are possible. Since so large a part of our resources is devoted to livestock production, it is clear that the considerable increases that are possible in the productivity of grassland, together with better utilization of the fodder provided and better stock management, could lead to an appreciable improvement in human nutritional standards.

Although, as we have seen, it is quite common for well-managed grass to give $25 \mathrm{cwt}$. starch equivalent per acre, the estimated yield in Table 5 is no more than $15 \mathrm{cwt}$. starch equivalent per acre. The whole process of utilization of home-grown foods could also be made materially more efficient. Thus from Table 5 it may be calculated that only $9 \%$ of the energy value of foods supplied to livestock is returned in the form of animal products for human consumption; this indicates that the actual efficiency attained is $20-25 \%$ lower than the theoretical values given in Table $\mathbf{I}$.

\section{REFERENCES}

Central Statistical Office (1950). Mon. Dig. Statist. no. 58.

Royal Society (1917). The Food Supply of the United Kingdom [Cd. 8421]. London: H.M. Stationery Office.

Yates, F. \& Boyd, D. A. (1949). Agric. Progr. 24, 14. 